\title{
Petrographic and Geochemical Characterization of Basalts in Bangangte Area (West Cameroon): Implications on Their Source
}

\author{
Pierre Wotchoko ${ }^{1}$, , Joëlle Flore Tene Djoukam², Gus Djibril Kouankap Nono ${ }^{1}$, \\ Patrice Arnaud Kouske $^{3}$, David Guymollaire Nkouathio ${ }^{4}$, Solange Atenkia Fonkem ${ }^{1}$ \\ ${ }^{1}$ Department of Geology, Higher Teacher Training College, University of Bamenda, Bambili, Bamenda, Cameroon \\ ${ }^{2}$ Department of Earth Sciences, Faculty of Sciences, University of Yaoundé 1, Yaoundé, Cameroon \\ ${ }^{3}$ Institute of Technology, University of Douala, Douala, Cameroon \\ ${ }^{4}$ Department of Earth Sciences, Faculty of Sciences, University of Dschang, Dschang, Cameroon
}

\section{Email address:}

pierrewotchoko@yahoo.fr (P. Wotchoko), joeflora2003@yahoo.fr (J. F. T. Djoukam), kouankap@yahoo.fr (G. D. K. Nono), arnaudpatricek@gmail.com (P. A. Kouske),nkouathio@yahoo.fr (D. G. Nkouathio), atenkiasolangefonkem@yahoo.com (S. A. Fonkem)

\section{To cite this article:}

Pierre Wotchoko, Joëlle Flore Tene Djoukam, Gus Djibril Kouankap Nono, Patrice Arnaud Kouske, David Guymollaire Nkouathio, Solange Atenkia Fonkem. Petrographic and Geochemical Characterization of Basalts in Bangangte Area (West Cameroon): Implications on Their Source. Earth Sciences. Vol. 4, No. 6, 2015, pp. 266-274. doi: 10.11648/j.earth.20150406.18

\begin{abstract}
The Bangangte area belongs to the Cameroon Volcanic Line. The volcanic rocks exposure in the area consist of fine microlitic porphiritic Basalts which still poorly surveyed. Petrographically, the studied rocks are made up of minerals like plagioclase, clinopyroxene, olivine phenocrysts and a lot of opaque minerals within a very fine grained matrice. The Bangangte basalts are quartz normative free and are olivine, Diopside, Hypersthene normative. Alkaline $\left(\mathrm{Na}_{2} \mathrm{O}+\mathrm{K}_{2} \mathrm{O}\right)$ contents vary from $2.247 \%$ to $5.46 \%$. These rocks are low-Mg basalts with the $\mathrm{Mg \#}$ values vary from 42.86 to 45.95 which are characteristic of primitive mantle source. The studied rocks are alkali to transitional basalts with $\mathrm{Nb} / \mathrm{Y}$ ratio $>1.5$. Chondrite normalized spider diagram pattern of REE shows uniform patterns with enrichment in LREE and a relative depletion in HREE. While MORB normalized spider diagram pattern of multi elements reveals a negative anomaly with $\mathrm{K}_{2} \mathrm{O}$, with enrichement in LILE and depletion in HREE. The Eu anomalies are positive to nulle and are typical of alkali basalts. The Bangangté transitional alkali basalts were formed in intraplate setting of continental part of the CVL. They are the products of partial melting of about $13 \%$ of an asthenosphere made up of garnet peridotite. Geochemically, the studied basalts are similar to alkali basalts from Mount Bamenda.
\end{abstract}

Keywords: Bangangte, CVL, Alkali to Transitional Basalts, Asthenosphere, Garnet Peridotite

\section{Introduction}

The West Cameroon region constitutes an integral part of the Cameroon Volcanic Line (CVL), which is a megastructure in central Africa oriented $\mathrm{N} 30^{\circ} \mathrm{E}$ and extending $\sim 2000 \mathrm{~km}$ in a length and $\sim 100 \mathrm{~km}$ in width. In Cameroon the tertiary volcanism seems to be related to a regional fracture trending $\mathrm{N} 30^{\circ} \mathrm{E}[1]$, reactivated during the tertiary volcanism, [2, 3, 4, 5].

Basaltic rocks of various affinities constitute the greatest proportion of exposed rocks in the west Cameroon where they form a series of plateau basalts on which numerous works have been done $[6,7,8]$. Basaltic rocks along the CVL are Alkaline, tholeiitic, and transitional with the alkali basalts been the most studied along the Cameroon Volcanic line [9, 10]. Transitional basalts in the Cameroon Line Contain mostly clino-pyroxenes, high iron, plagioclases and are found to be within plate basalts [11]. Subalkaline, tholeiitic rocks are enriched in Fe relative to $\mathrm{Mg}$, compared to calc-alkaline rocks, while silica remains relatively the same [12].

Investigation of basalts has been a subject of very few researchers in Bangangte area. In this paper, we present the preliminary data of transitional to alkalic basalts from Bangangte area, this include detailed petrographic description and whole rock geochemical characterization with the aim to constraint the source of their magma; therefore contribute to the knowledge database of the CVL. 


\section{Geological Setting}

The Bangangte area $\left(10^{\circ} 29^{\prime}-10^{\circ} 42^{\prime} \mathrm{E}\right.$ and $\left.5^{\circ} 2^{\prime}-5^{\circ} 15^{\prime} \mathrm{N}\right)$ is located along the Cameroon Volcanic Line (CVL) which extends from the island of Pagalu in the Atlantic ocean through the Gulf of Guinea up to the Lake Chad [13, 14, 15, 16]. The volcanism along the CVL began during the Eocene with the emplacement of the Bamoun plateau between 51.8 and 46.7 Ma [17] and mount Bangou between 44.7 and 43.1 $\mathrm{Ma}$ [8] and is still active, Mount Cameroon in 1999 and 2000 eruptions [18].

The CVL (Fig. 1) shows characteristic alignments of volcanoes, anorogenic complexes and grabens. The anorogenic complexes (about sixty: [19]) occur only on the continental section along the Cameroon Volcanic Line. They contain a range of rock types from very basic through intermediate to acid and have both plutonic and volcanic facies. The anorogenic complexes are therefore termed plutonic-volcanic anorogenic complexes [20]. The investigated massifs are composed of gabbros, diorites, monzonites, syenites and granites, and associated slightly younger volcanic rocks such as basalts, trachytes, phonolites and rhyolites (e.g., $[21,22,20])$. Basalts along the Cameroon Volcanic Line showed that they were derived from a depleted asthenospheric source beneath the sub continental lithosphere $[23,24]$, or from amphibole-bearing lithospheric mantle for the continental basalts [25]. Geophysical studies revealed that the Cameroon Volcanic Line is underlain by a thin crust of ca 30-34 km thickness [26, 27, 28]. The CVL origin has been the subject of several studies [25, 29, 16]. Recent studies suggest that the Cameroon Line follows a major structural zone in the lithosphere [28]. Bangangté area has a crystalline basement covered by volcanic projections which have not yet been studied in details.

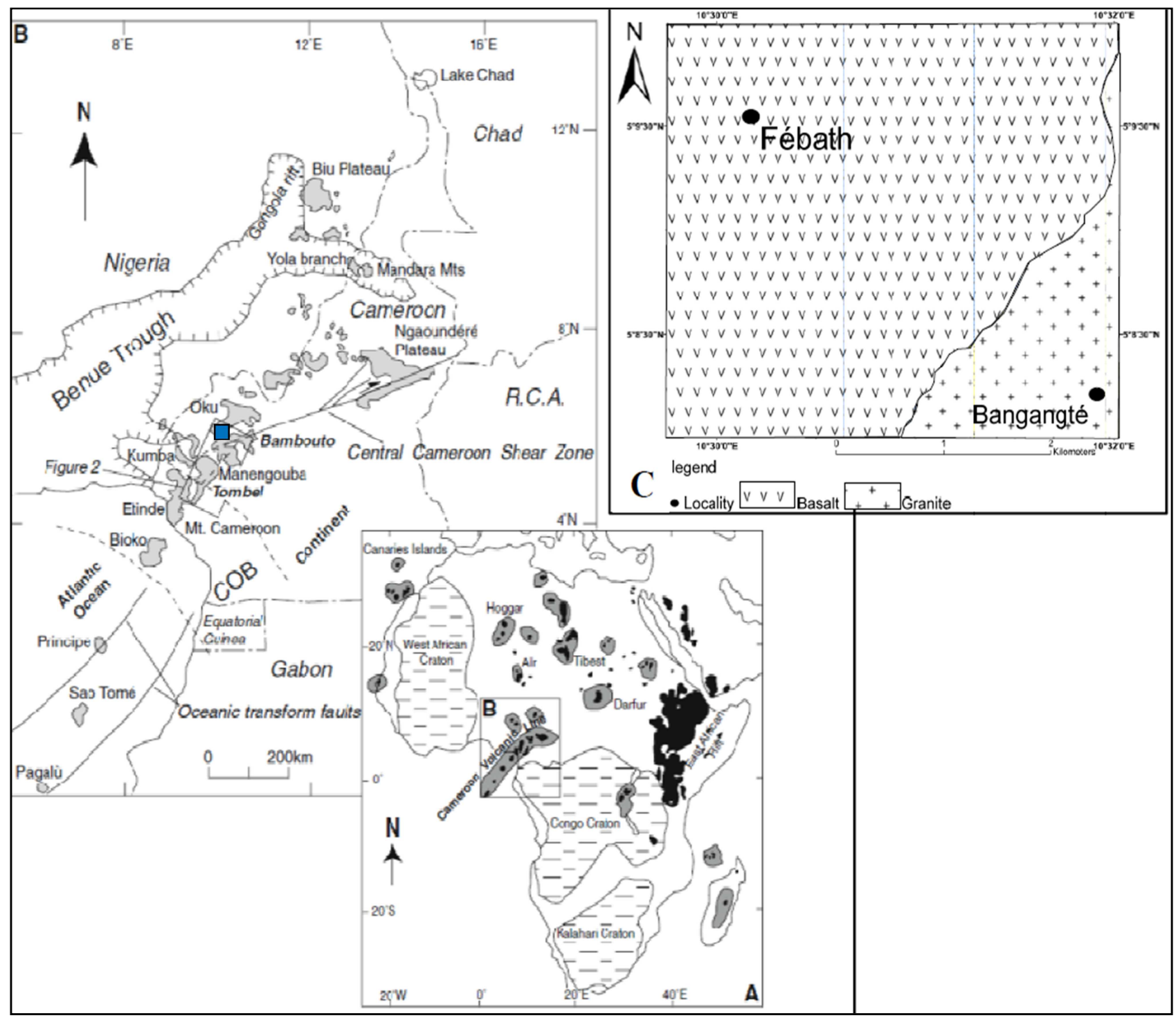

Figure 1. Location map and geological map of the study area; Modified after [30].

A) Location of CVL with other African major features, B) location of the CVL within a Cameroon map, the blues square represents the approximate position of Bangangté area, C) Sketch of geological map of Bangangté area showing the granitic basement cover by the volcanic rock. 


\section{Analytical Methods}

Selected fresh samples were sent to Geotech lab Vancouver for thin sections and Nine (09) representative samples were sent to ALS Commercial Laboratories Canada for whole rock geochemistry.

For whole rock geochemistry, all the samples were pulverized to obtain homogenous samples. Analysis ofmajor oxides and trace elements was done by: Inductively Coupled Plasma - Atomic Emission Spectroscopy (ICP-AES).A prepared sample $(0.200 \mathrm{~g})$ is added to lithium metaborate/lithium tetraborate flux $(0.90 \mathrm{~g})$, mixed well and fused in a furnace at $1000^{\circ} \mathrm{C}$. The resulting melt is then cooled and dissolved in $100 \mathrm{~mL}$ of $4 \%$ nitric acid $/ 2 \%$ hydrochloric acid. This solution is then analyzed by ICPAES and the results are corrected for spectral inter-element interferences. Oxides concentrations were calculated from the determined elemental concentration and the result was reported. The total oxide content is determined from the ICP analyte concentrations and loss on Ignition (L.O.I.) values. A prepared sample $(1.0 \mathrm{~g})$ is placed in an oven at $1000^{\circ} \mathrm{C}$ for one hour, cooled and then weighed. The percent loss on ignition is calculated from the difference in weight.

\section{Petrography}

Basalts in the study area occur both as blocks and massifs (Fig 2; A \& B). The hand specimens are dark gray to black, dense and made up of fine grains minerals. Some samples contain cavities filled by quartz crystals. The main minerals that could be identified on the hand specimen are olivine and plagioclases.

Under the cross-polarized light microscope, the studied basalts from Bangangté area mainly have porphyritic textures (Fig2: C \& D) and contain phenocrysts of olivine, clinopyroxenes, plagioclase and abundant opaque minerals.
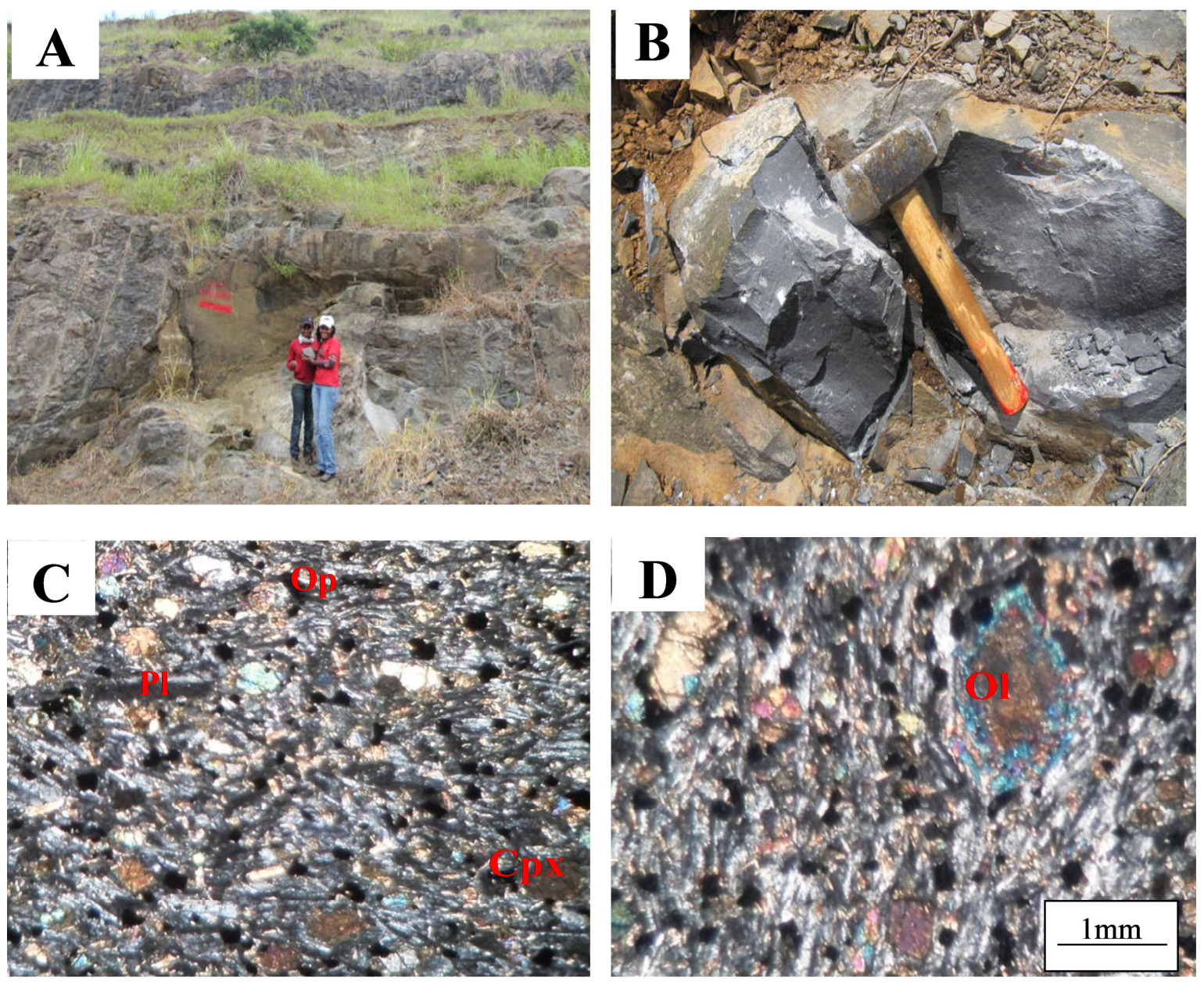

Figure 2. Photographs $(A \& B)$ and photomicrographs $(C \& D)$ of basalts from Bangangté area.

Olivine occurs as euhedral, subhedral or skeletal crystals, and makes up to $25 \%$ of the total volume of rock. They are about $0.002 \mathrm{~mm}$ to $0.01 \mathrm{~mm}$ in diameter and show irregular cracks, cleavages and slide alteration. Plagioclases phenocrysts are $45 \%$ of the total volume with dimensions of about $0.005 \mathrm{~mm}$ to $0.002 \mathrm{~mm}$. Large plagioclase phenocrysts range from 5 to $15 \mathrm{~mm}$ in length. The groundmass is dominated by plagioclase microlites. Clinopyroxenes 
constitute about $10 \%$ of the total volume and are about $0.002 \mathrm{~mm}$ to $0.001 \mathrm{~mm}$ in length mostly as microlites isolated in the groundmass. Opaque minerals are fine sub rounded crystals occur in the groundmass. They occupy about $20 \%$ of the total rock volume and are about $0.003 \mathrm{~mm}$ to $0.001 \mathrm{~mm}$ in diameter.

\section{Geochemstry}

\subsection{Major Elements}

Major elements concentrations are listed in Table 1.Contents of $\mathrm{SiO}_{2}, \mathrm{Al}_{2} \mathrm{O}_{3}, \mathrm{TiO}_{2}$ and $\mathrm{MgO}$ in the studied rocks are $45.6 \%-47.5 \%, 14.0 \%-14.45 \%, 2.64 \%-2.79,6.24 \%$ -
$6.82 \%$ respectively. Alkaline $\left(\mathrm{Na}_{2} \mathrm{O}+\mathrm{K}_{2} \mathrm{O}\right)$ contents vary from between $4.27 \%$ to and $5.46 \%$. The total alkaline versus silica diagram of [31] shows that all the samples are alkaline basalts (Fig3: A). The MgO content ( $<08 \%$ wt) traduce the low-Mg characteristic of the studied rocks which confirm their alkali properties (Fig3: B). The Mg\# varies from 42.86 to 45.95 , indicating that the lavas of the studied rocks are from primitive mantle and has undergone little fractionation. Except for samples BB1b1 (1.328) and BB2a2 (0.916) the studied rocks are quartz normative free, also these two samples are olivine normative free while the remains rocks are olivine, Diopside, Hypersthene normative.

Table 1. Major element contents and CIPW norms of alkali basalts from Bangangté.

\begin{tabular}{|c|c|c|c|c|c|c|c|c|c|}
\hline Wt (\%) & BB1b1 & BB1b2 & BB2a1 & BB2a2 & BB2a3 & BB4d1 & BB6C1 & BB6C2 & BB6C3 \\
\hline $\mathrm{SiO}_{2}$ & 47,4 & 46,3 & 45,6 & 46,5 & 46,3 & 45,9 & 47,1 & 47,1 & 47,5 \\
\hline $\mathrm{TiO}_{2}$ & 2,7 & 2,64 & 2,68 & 2,71 & 2,75 & 2,71 & 2,72 & 2,72 & 2,79 \\
\hline $\mathrm{Al}_{2} \mathrm{O}_{3}$ & 14,25 & 14,1 & 14 & 14,2 & 14,15 & 14 & 14,3 & 14,3 & 14,45 \\
\hline $\mathrm{Fe}_{2} \mathrm{O}_{3}$ & 13,6 & 13,55 & 13,45 & 13,55 & 13,7 & 13,7 & 13,7 & 13,85 & 14,05 \\
\hline $\mathrm{MnO}$ & 0,2 & 0,19 & 0,19 & 0,2 & 0,2 & 0,2 & 0,2 & 0,2 & 0,2 \\
\hline $\mathrm{MgO}$ & 6,41 & 6,38 & 6,66 & 6,7 & 6,82 & 6,24 & 6,28 & 6,39 & 6,53 \\
\hline $\mathrm{CaO}$ & 8,57 & 8,17 & 8,15 & 8,43 & 8,32 & 8,3 & 8,43 & 8,51 & 8,6 \\
\hline $\mathrm{K}_{2} \mathrm{O}$ & 1,04 & 1,22 & 1,19 & 0,99 & 1,15 & 1,18 & 1,25 & 1,27 & 1,24 \\
\hline $\mathrm{P}_{2} \mathrm{O}_{5}$ & 0,61 & 0,6 & 0,61 & 0,61 & 0,63 & 0,61 & 0,62 & 0,61 & 0,63 \\
\hline TOTAL & 98,18 & 97,01 & 96,25 & 97,17 & 97,78 & 96,94 & 98,69 & 99,11 & 100,21 \\
\hline $\mathrm{Mg \#}$ & 44,44 & 44,44 & 45,95 & $\begin{array}{l}45,95 \\
\text { CIPW }\end{array}$ & $\begin{array}{l}45,95 \\
\text { NORM }\end{array}$ & 42,86 & 44,44 & 44,44 & 43,24 \\
\hline Q & 1.328 & 0.000 & 0.000 & 0.916 & 0.000 & 0.000 & 0.000 & 0.000 & 0.000 \\
\hline Or & 6.146 & 7.210 & 7.033 & 5.851 & 6.796 & 6.973 & 7.387 & 7.505 & 7.328 \\
\hline An & 20.549 & 17.543 & 17.987 & 21.099 & 18.335 & 16.311 & 16.968 & 16.594 & 16.823 \\
\hline Di & 7.287 & 8.265 & 7.683 & 6.292 & 7.808 & 9.516 & 9.429 & 10.079 & 9.958 \\
\hline Hy & 12.588 & 5.281 & 5.417 & 13.772 & 6.269 & 0.031 & 2.388 & 0.132 & 0.001 \\
\hline $\mathrm{Ol}$ & 0.000 & 4.750 & 5.333 & 0.000 & 4.975 & 7.779 & 6.225 & 7.787 & 8.162 \\
\hline Il & 0.428 & 0.406 & 0.406 & 0.428 & 0.428 & 0.428 & 0.428 & 0.428 & 0.428 \\
\hline $\mathrm{Hm}$ & 13.600 & 13.550 & 13.450 & 13.550 & 13.700 & 13.700 & 13.700 & 13.850 & 14.050 \\
\hline $\operatorname{Tn}$ & 6.075 & 5.956 & 6.054 & 6.100 & 6.198 & 6.100 & 6.124 & 6.124 & 6.296 \\
\hline Ap & 1.445 & 1.421 & 1.445 & 1.445 & 1.492 & 1.445 & 1.469 & 1.445 & 1.492 \\
\hline
\end{tabular}
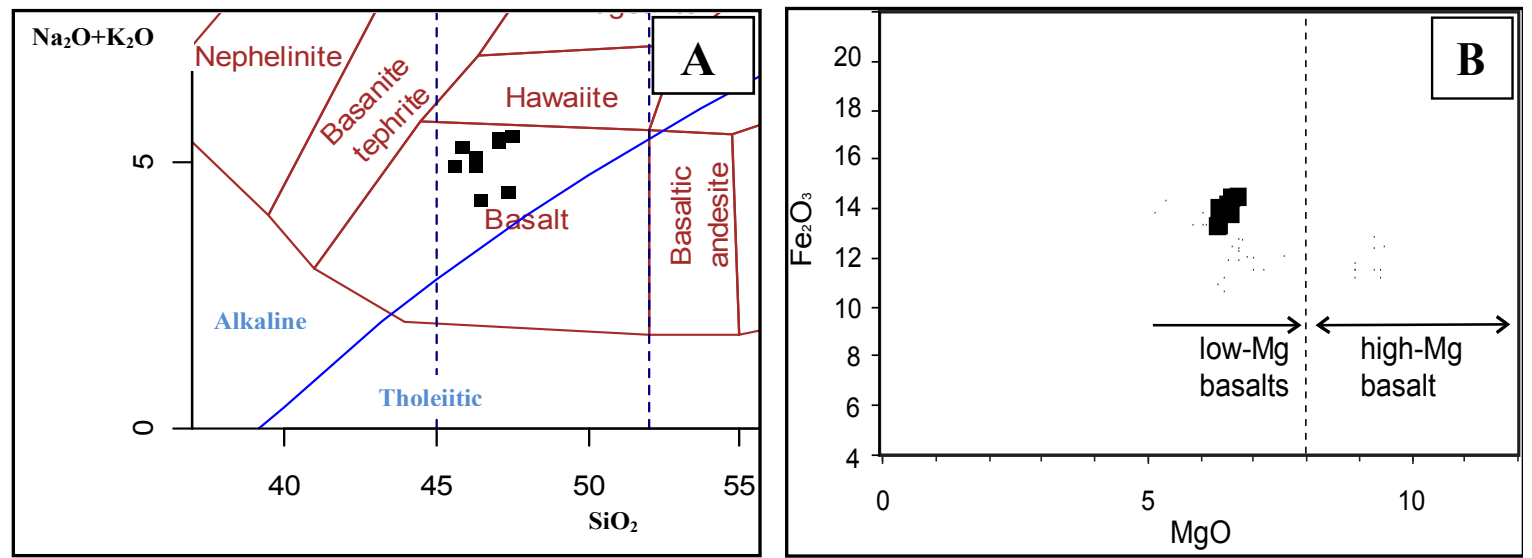

Figure 3. Bangangte Basalts plotted in the classification diagram of [31] and Fe2O3 versus MgO classification diagram showing the characteristic of low-Mg of these rocks.

\subsection{Trace and Rare Earth Elements}

Trace elements and rare earth elements contents of alkali basalts from Bangangté are listed in Table2. The sum of REE is comprised between $182.79 \mathrm{ppm}$ and $197.02 \mathrm{ppm}$. The ratio values of $(\mathrm{La} / \mathrm{Yb})_{\mathrm{N}},(\mathrm{Gd} / \mathrm{Yb})_{\mathrm{N}}$ and $(\mathrm{Ce} / \mathrm{Sm})_{\mathrm{N}}$ are respectively 
$10.987-11.572 ; 2.740-3.005$ and 2.019-2.146. Based on the binary diagram $\mathrm{TiO}_{2}$ versus $\mathrm{Nb}$ (Fig4) the studied basalts are transitional and based on the ratio $\mathrm{Nb} / \mathrm{Y}$ which is $>1.5$, the studied basalts are alkaline.

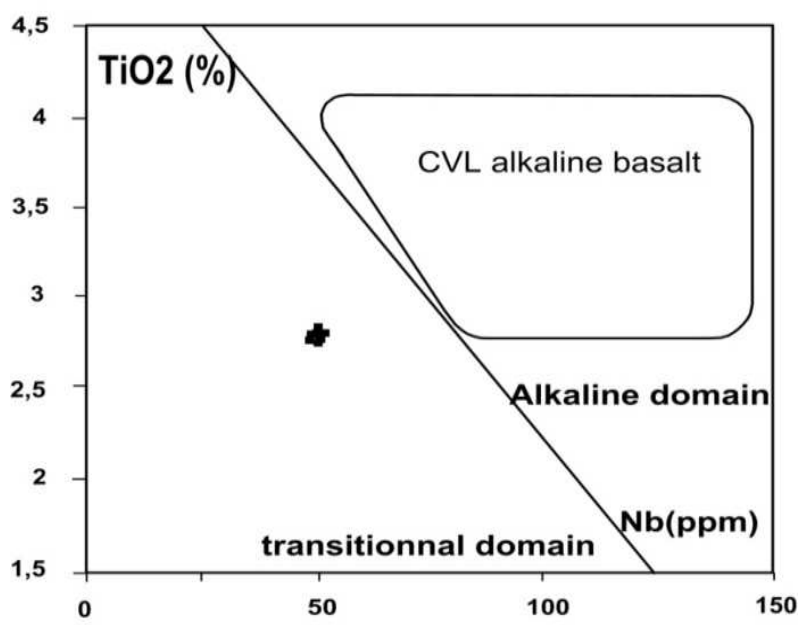

Figure 4. Bangangte basalts within the $\mathrm{TiO}_{2}$ versus $\mathrm{Nb}$ diagram according to [32].

The values of $\mathrm{Eu} / \mathrm{Eu}^{*}$ are $\geq 1.05$ in samples $\mathrm{BB} 1 \mathrm{~b} 1$, BB1b2, BB2a3 and BB6c1 (positive anomalies in Eu). These values of $\mathrm{Eu} / \mathrm{Eu}^{*}$ values are between 0.96-1.04 (nulle anomalies in Eu) in samples BB2a1, BB2a2, BB4d1, BB6c2, BB6c3.The REE spider diagram normalized with Chondrite
[33] shows uniform patterns having a slight enrichment in LREE and a slight depletion HREE (Fig.5), this REE pattern show no significant negative anomalies in $\mathrm{Eu}$, which is typical for alkali basalt. Multi-element spider diagram normalized with MORB [34] shows a negative anomaly for $\mathrm{K}_{2} \mathrm{O}$. It also shows enrichment in LILE and depletion in LREE and HREE (Fig.6).

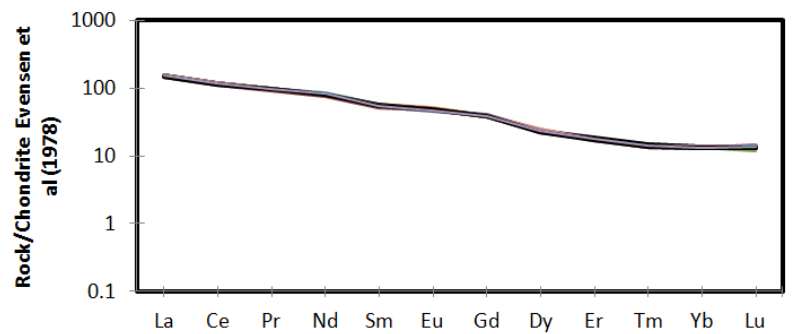

Figure 5. REE spider diagram normalized with Chondrite [33].

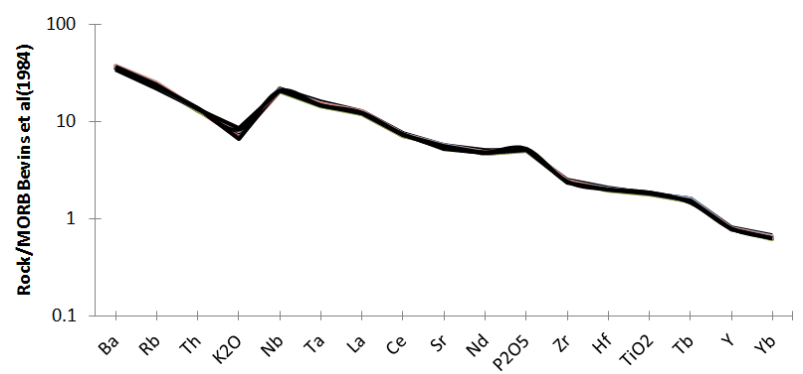

Figure 6. Multi-elements spider diagram normalized with MORB [34].

Table 2. Trace elements and rare earth elements of alkali basalts from Bangangté.

\begin{tabular}{|c|c|c|c|c|c|c|c|c|c|}
\hline ppm & BB1b1 & BB1b2 & BB2a1 & BB2a2 & BB2a3 & BB4d1 & BB6C1 & BB6C2 & BB6C3 \\
\hline $\mathrm{Ba}$ & 438 & 440 & 419 & 441 & 412 & 435 & 454 & 435 & 430 \\
\hline $\mathrm{Rb}$ & 24,2 & 23,4 & 22,6 & 24 & 21,8 & 23,3 & 25 & 24,2 & 23,1 \\
\hline Th & 2,59 & 2,52 & 2,71 & 2,73 & 2,68 & 2,69 & 2,67 & 2,67 & 2,74 \\
\hline $\mathrm{Nb}$ & 50,3 & 50,4 & 52,6 & 54,4 & 52,4 & 52,8 & 52,4 & 51,5 & 51,6 \\
\hline $\mathrm{Sr}$ & 785 & 773 & 748 & 775 & 710 & 770 & 757 & 752 & 744 \\
\hline $\mathrm{Ta}$ & 2,6 & 2,4 & 2,6 & 2,7 & 2,6 & 2,6 & 2,6 & 2,5 & 2,5 \\
\hline $\mathrm{Y}$ & 28,5 & 28,6 & 29,4 & 30,1 & 29,2 & 29,6 & 29,2 & 28,8 & 29,3 \\
\hline $\mathrm{Zr}$ & 212 & 209 & 211 & 221 & 212 & 210 & 213 & 208 & 213 \\
\hline $\mathrm{Ga}$ & 18,4 & 18,8 & 19,5 & 20,4 & 19,5 & 18,9 & 19,2 & 19,2 & 19,2 \\
\hline V & 192 & 191 & 192 & 203 & 194 & 196 & 194 & 192 & 197 \\
\hline $\mathrm{Hf}$ & 5 & 4,8 & 5,1 & 5,2 & 5,1 & 5,1 & 5 & 4,9 & 5 \\
\hline $\mathrm{Sn}$ & 2 & 2 & 2 & 2 & 2 & 2 & 2 & 2 & 2 \\
\hline $\mathrm{U}$ & 0,64 & 0,67 & 0,72 & 0,76 & 0,68 & 0,72 & 0,64 & 0,62 & 0,65 \\
\hline $\mathrm{Cs}$ & 0,12 & 0,14 & 0,17 & 0,18 & 0,15 & 0,21 & 0,2 & 0,26 & 0,2 \\
\hline $\mathrm{La}$ & 35,6 & 35,4 & 37 & 38,4 & 36,7 & 36,9 & 37,8 & 36,7 & 36,9 \\
\hline $\mathrm{Ce}$ & 71,1 & 71,1 & 74,2 & 76,4 & 74 & 74,1 & 74,8 & 72,9 & 74,2 \\
\hline $\operatorname{Pr}$ & 8,98 & 9,07 & 9,41 & 9,64 & 9,34 & 9,38 & 9,46 & 9,16 & 9,43 \\
\hline $\mathrm{Nb}$ & 50,3 & 50,4 & 52,6 & 54,4 & 52,4 & 52,8 & 52,4 & 51,5 & 51,6 \\
\hline $\mathrm{Sm}$ & 8,14 & 8,4 & 8,45 & 8,94 & 8,56 & 8,77 & 8,33 & 8,41 & 8,36 \\
\hline $\mathrm{Eu}$ & 2,79 & 2,77 & 2,75 & 2,9 & 2,89 & 2,76 & 2,82 & 2,78 & 2,69 \\
\hline $\mathrm{Gd}$ & 7,74 & 7,64 & 8,08 & 8,18 & 7,82 & 7,74 & 7,84 & 7,84 & 7,85 \\
\hline $\mathrm{Tb}$ & 1,13 & 1,12 & 1,19 & 1,21 & 1,16 & 1,19 & 1,14 & 1,15 & 1,1 \\
\hline Dy & 5,72 & 5,67 & 6 & 6,28 & 6,05 & 5,9 & 6,06 & 5,76 & 5,95 \\
\hline Ho & 1,16 & 1,11 & 1,13 & 1,22 & 1,24 & 1,18 & 1,23 & 1,17 & 1,17 \\
\hline $\mathrm{Er}$ & 2,93 & 2,85 & 2,97 & 2,98 & 2,85 & 3,02 & 2,88 & 2,84 & 2,91 \\
\hline $\mathrm{Tm}$ & 0,36 & 0,35 & 0,35 & 0,39 & 0,35 & 0,38 & 0,35 & 0,35 & 0,36 \\
\hline
\end{tabular}




\begin{tabular}{|c|c|c|c|c|c|c|c|c|c|}
\hline ppm & BB1b1 & BB1b2 & BB2a1 & BB2a2 & BB2a3 & BB4d1 & BB6C1 & BB6C2 & BB6C3 \\
\hline $\mathrm{Yb}$ & 2,17 & 2,15 & 2,18 & 2,35 & 2,22 & 2,29 & 2,26 & 2,19 & 2,2 \\
\hline $\mathrm{Lu}$ & 0,36 & 0,3 & 0,34 & 0,36 & 0,33 & 0,33 & 0,33 & 0,33 & 0,34 \\
\hline$(\mathrm{Ce} / \mathrm{Sm}) \mathrm{N}$ & 2,087 & 2,022 & 2,098 & 2,042 & 2,066 & 2,019 & 2,146 & 2,071 & 2,121 \\
\hline$(\mathrm{La} / \mathrm{Yb}) \mathrm{N}$ & 11,186 & 11,226 & 11,572 & 11,141 & 11,271 & 10,987 & 11,404 & 11,426 & 11,436 \\
\hline$(\mathrm{Gd} / \mathrm{Yb}) \mathrm{N}$ & 2,892 & 2,881 & 3,005 & 2,822 & 2,856 & 2,740 & 2,813 & 2,903 & 2,893 \\
\hline$(\mathrm{Ce} / \mathrm{Yb}) \mathrm{N}$ & 8,699 & 8,780 & 9,036 & 8,631 & 8,850 & 8,591 & 8,787 & 8,837 & 8,954 \\
\hline $\mathrm{Eu} / \mathrm{Eu}^{*}$ & 1,1 & 1,09 & 1,05 & 1,07 & 1,12 & 1,06 & 1,1 & 1,08 & 1,06 \\
\hline
\end{tabular}

\section{Discussion}

Source of magma and geotectonic context

The $\mathrm{Mg} \#$ values of Bangangté basalts which are $<50$ show that their parent magma may come from primitive mantle magma. According to previous work in [35], basalts which come from asthenosphere typically have the characteristics of $\mathrm{La} / \mathrm{Nb}<1.5$ and $\mathrm{La} / \mathrm{Ta}<22$ while basalts from lithosphere are on contrary [36]. The ratio $\mathrm{La} / \mathrm{Nb}$ of transitional alkalic basalts from Bangangté varies from 0.70 to 0.72 , and $\mathrm{La} / \mathrm{Ta}$ from 13.69 to 14.76 ; which may simply shows that the parent magma of the studied rocks may come from mantle asthenosphere. The ratio $\mathrm{Zr} / \mathrm{Nb}<20$ confirm also a mantle source as indicates by the binary diagram $\mathrm{Zr} / \mathrm{Nb}$ versus $\mathrm{MgO}$ (Fig7: A). On the other binary diagram $\mathrm{Zr} / \mathrm{Nb}$ versus $\mathrm{Zr}$ the Bangangté studied basalts are plotted in the field of mantle source (Fig7: B)
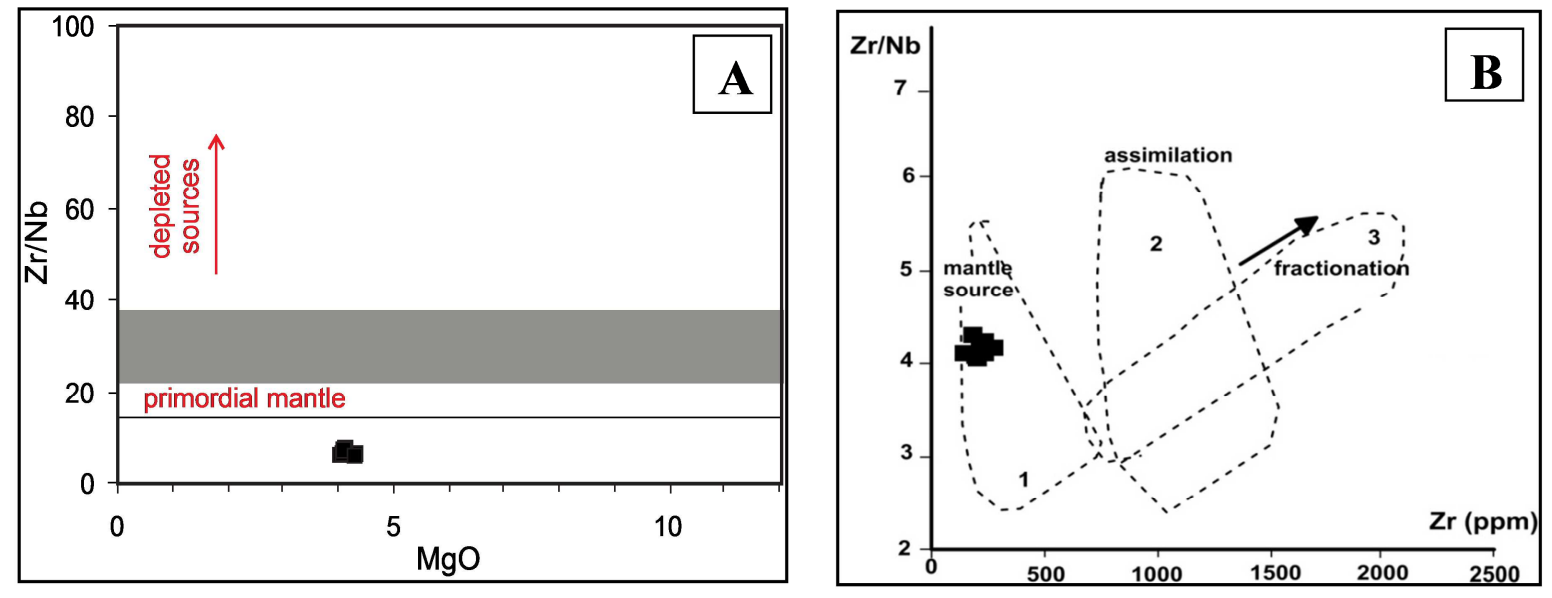

Figure 7. A) Bangangte basalt within the $\mathrm{TiO}_{2}$ versus $\mathrm{Nb}$ diagram according to [32]. B) $\mathrm{Zr} / \mathrm{Nb}$ versus $\mathrm{Zr}$ diagram for Bangangte basalts.

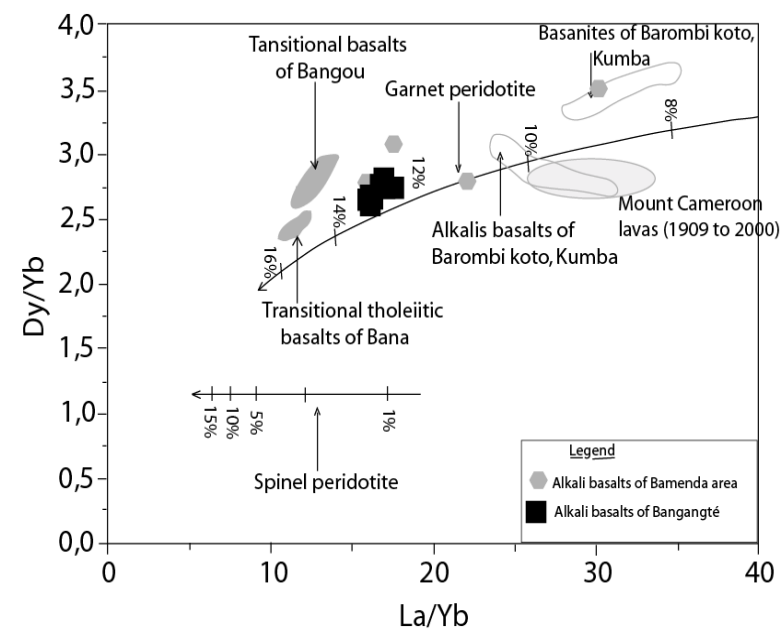

Figure 8. La/Yb versus $D y / Y b$ diagram for rocks from Bangangte. Melt curves for garnet peridotite and spinel peridotite [37]. Also shown are the basic lavas from Mounts Cameroon [38, 39].

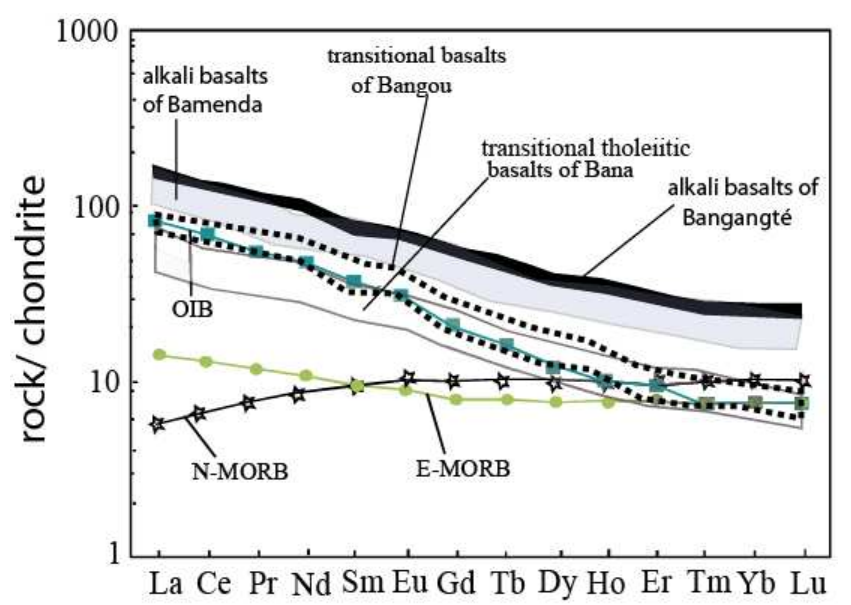

Figure 9. Comparative chondrite-normalized REE parttens of Bangangté alkali basalt with some relevant most studied basalts.

Basaltic lavas originate from different sources with variable proportions. A chemically homogeneous mantle can yield a variety of basalt types from partial melting of peridotite. Plotted in the binary diagram $\mathrm{La} / \mathrm{Yb}$ versus $\mathrm{Dy} / \mathrm{Yb}$ 
[37] showing the melt curves for garnet peridotite and spinel peridotite, the studied Bangangte basalts were originated from partial melting of garnet peridotite at about $13 \%$ melting (Fig8). This source is similar to the one of alkali basalts from Mont Bamenda [9].

When comparing REE contents and REE chondritenormalized patterns of Bangangte alkali basalts, it is clearly appear that, their patterns are parallels to the one of Bamenda alkali basalts and even to the one of OIB, the slide differences being the various elements contents which are higher in Bangangté alkali basalts (Fig.9).

This geotectonic discrimination binary diagram $\mathrm{Zr} / \mathrm{Y}-\mathrm{Zr}$ [40] reveals that the transitional alkali basalts from Bangangte are within plate basalts (Fig10).

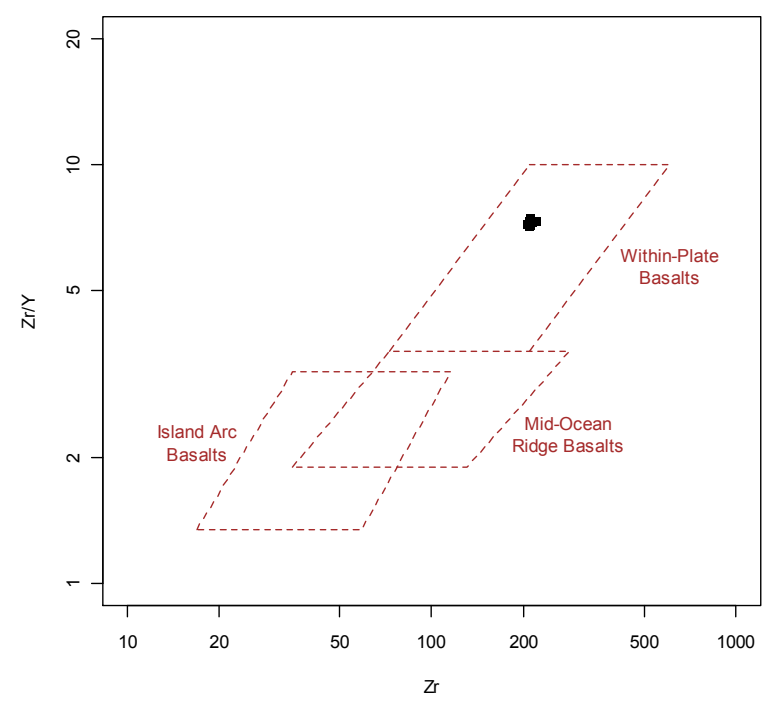

Figure 10. Geotectonic discrimination diagram of basaltic rocks [40].

\section{Conclusion}

Bangangte Basalt petrographicallyisa dark massive volcanic rock having few cavities filled of quartz. The studied rocks yield microliticporphirtic texture made up of minerals like plagioclase, clinopyroxenes, olivine phenocrysts and a lot of opaque minerals within a ground mass.

The Geochemical analysis shows that the Bangangte basalts are transitional alkali basalts. The alkaline contents vary from $4.27 \%$ to $5.46 \%$.The $\mathrm{MgO}$ content $(<08 \% \mathrm{wt})$ traduce the low-Mg characteristic of the studied rocks which confirm their alkali properties. The $\mathrm{Mg} \#$ varie from 42,86 to 45,95 , indicating that the lavas of the studied rocks are from primitive mantle and has undergone little fractionation. Except for samples BB1b1 $(1,328)$ and BB2a2 $(0,916)$ the studied rocks are quartz normative free, also these two samples are olivine normative free while the remains rocks are olivine, Diopside, Hypersthene normative. The $\mathrm{Mg \#}$ values of Bangangté basalts which are $<50$ show that their parent magma may come from primitive mantle magma.

Chondrite normalized spider diagram pattern of REE shows uniform patterns with enrichment in LREE and relative depletion in HREE. While MORB normalized spider diagram pattern of multi elements reveals a negative anomaly with $\mathrm{K}_{2} \mathrm{O}$, with enriched LILE and depletion in HREE. The $\mathrm{Eu}$ anomalies are positive to nulle. The Bangangté transitional to alkali basalts were formed in intraplate setting of continental part of the CVL. They are the products of partial melting of about $13 \%$ of an asthenosphere made up of garnet peridotite. Geochemically, the studied basalts are similar to alkali basalts from Mount Bamenda.

\section{Acknowledgment}

The authors are grateful to anonymous reviewers who provided useful critiques which upgrade the quality of this paper.

\section{References}

[1] Gountie D. M., Nono A., Njonfang E., Kamgang P., Zangmo T. G., Kagou D. A., Nkouathio D. G., 2009. Le volcanisme ignimbritique des monts Bambouto et Bamenda (Ligne du Cameroun, Afrique Centrale): Signification dans la formation des caldeiras. Bulletin de l'institut scientifique. 2011, n³3, P. $1-15$.

[2] Fitton J.G., 1983 “Active versus Rifting: Evidence from the west Africa,"Tectonophysics, Vol.94, No.1-4, pp.473-481.

[3] Njonfang E., 1998, "Contribution à L'étude de la Relation entre la 'Ligne du Cameroun' et la Direction de l'Adamawa: 1- Pétrologie, Géochimie et Structure des Granitoid africains de la Zone de Cisaillement Foumban- (Ouest-Cameroun et Adamawa). 2-Pétrologie et Géo- chimie des Formations Magmatiques Tertiaires Associées," Thèse de Doctorat d'Etat, Université of Yaoundé I, Yaoundé, p. 379.

[4] Moreau C., Regnoult J.M., Déruelle B., Robineau B., 1987. A new tectonic model for the Cameroon Line, Central Africa. Tectonophysics 139, 317-334.

[5] Guiraud R. M., Binks C. S, Fairhe Szabo J. D., Fairhead and Wilson M., 1992 "Chronology and Geodynamic Set- ting of Cretaceous-Cenozoic Rifting in West and Central Africa," Tectonophysics, Vol. 213, No. 1-2, pp.234.

[6] Moundi A., 2004. Les basaltes des plateaux du plateau Bamoun: Pétrologie-géochimie et géochronologie. Implications sur les sources des magmas, contexte et évolution géodynamiques. The 'se de Doctorat d'Etat, Université' de Yaounde' I, Cameroun, 208p.

[7] Kuepouo, G., 2004. Geology, Petrology and Geochemistry of the Tertiary Bana Volcano-Plutonic Complex, Cameroon Line, Central Africa. Ph.D. Thesis, Kobe University, Japan, $301 \mathrm{p}$.

[8] Fosso J., Me'nard J.J., Bardinzeff J.M., Wandji P., Tchoua F.M., Bellon H., 2005. Les laves du mont Bangou: une première manifestation volcanique Eocène a affinité transitionnelle de la ligne de Cameroun. Comptes Rendus des Geosciences 337, 315-325.

[9] Kamgang P., Chazot G., Njonfang E., Tchoua, F., 2008. Geochemistry and Geochronology of mafic rocks from Bamenda Mountains (Cameroon): Source composition and crustal contamination along the Camroon line. Comptes rendus Geoscience. 
[10] Ngounouno I., Deruelle B., Guiraud R., and Vicat J. P., 2001. Magmatismes tholéiitique et alcalin des demi-grabens crétacés de Mayo Oulo-Léré et de Babouri-Figuil (Nord du CameroonSud du chad) en domaine d'extension continentale. Comptes rendus Academie des Sciences de Paris. 333 (2001) 201-207.

[11] Kuepouo G., Tchouankoue JP., Nagao T., Sato H., 2006. Transitional tholeiitic basalts in the Tertiary Bana volcanoplutonic complex, Cameroon Line. J African Earth Science: 45: 318-32.

[12] Best M.G., 2003. Igneous and Metamorphic Petrology. Blackwell Publishing. 2nd Edition. PP. 35-36.

[13] Fitton J.G., 1987. The Cameroon Line, Africa: a comparison between Oceanic and continental alkaline volcanism. In: Fitton, J.G., Upton, B.G.J. (Eds.), Alkaline Igneous Rocks, Special Publication, vol. 30. Geological Society, London, pp. 273-291.

[14] Lee D.C., Halliday A.N., Fitton J.C., Poli G., 1994. Isotopic variations with distance and time in the volcanic islands of the Cameroon line: evidence for the plume origin. Earth and Planetary Sciences Letters 123, 119-138.

[15] Déruelle B., Moreau C., Nkoumbou C., Kambou R., Lissom J., Njonfang E., Nono A., 1991. The Cameroon Line: A Review. In: Kampunzu, A.B., Lubala, R.T. (Eds.), Magmatism in Extensional Tectonic Structural Settings. Springer, Berlin, pp. 274-327.

[16] Déruelle B., Ngounouno I., and Demaiffe D., 2007. "The Cameroon Hot Line (CHL): A Unique Example of Active Alkaline Intraplate Structure in both Oceanic and Continental Lithospheres," Comptes Rendus Geosciences 339, No. 9, pp. 589-600.

[17] Moundi, A., Wandji, P., Bardintzeff, J.-M., Ménard, J.-J., Okomo Atouba, L.C., Mouncherou, O.F., Reusser, E., Bellon, H., Tchoua, F.M., 2007. Les basaltes éocènes à affinité transitionnelle du plateau Bamoun, témoins d'un réservoir mantellique enrichi sous la ligne volcanique du Cameroun. C.R. Geoscience 339, 396-406.

[18] Suh C. E., Sparks R. S. J., Fitton J. G., Ayonghe S. N., Annen C., Nana R and Luckman A., 2003 "The 1999 and 2000 Eruptions of Mount Cameroon. Bulletin of Volcano. No. 4, pp. 267-281.

[19] Lasserre M., 1978. Mise au point sur les granitoïdes dits "ultimes" du Cameroun. Gisement, petrographie et geochronologie. Bulletin du Bureau de Recherches Geologiques et Miniere 2, 145-159.

[20] Njonfang E., Kamgang P., Ghogomu T.R., Tchoua F.M., 1992. The geochemical characteristics of some plutonic-volcanic complexes along the southern part of the Cameroon Line. Journal of African Earth Sciences 14, 255-266.

[21] Nana J.M., 1988. Le complexe volcano-plutonique de Bana (Ouest Cameroun). Geologie et petrologie. These de Doctorat. Universite de Paris XI, France.

[22] Ghogomu R.T., Moreau C., Brown W.L., Rocci G., 1989. The Ntumbaw complex, NW Cameroon: an atypical anorogenic ring complex of intermediate composition. Journal of African Earth Sciences 8, 1-9.

[23] Halliday A.N., Dickin, Fallick A.P., Fitton J.G., 1988. Mantle dynamics: a $\mathrm{Nd}, \mathrm{Sr}, \mathrm{Pb}$ and $\mathrm{O}$ isotopic study of the Cameroon Line volcanic Chain. Journal of Petrology 29, 181-211.

[24] Sato H., Aramaki S., Kusakabe M., Hirabayashi J.-I., Sano Y.,
Nojiri Y., Tchoua F., 1990. Geochemical difference of basalts between polygenetic and monogenetic volcanoes in the central part of the Cameroon volcanic line, Geochem. J. 24, 357-370.

[25] Marzoli A., Renne P.R., Piccirillo E.M., Francesca C., Bellieni G., Melfi A.J., Nyobe J.B., N'ni J., 2000. The Cameroon Volcanic Line Revisited: Petrogenesis of continental basaltic magmas from lithospheric and asthenospheric mantle sources. Journal of Petrology 41, 87-109.

[26] Fairhead J.D., Okereke C.S., 1987. A regional study of the West African Rift system in Nigeria and Cameroon and its tectonic interpretation. Tetctonophysics 143, 141-159.

[27] Plomerova, J., Babuska, V., Dorbath, C., Dorbath, L., Lillie, R.J., 1993. Deep lithospheric structure across the Central African shear zone in Cameroon. Geophysical Journal International 115, 381-390.

[28] Poudjom D.Y.H., Diament M., Wilson M., 1997. Lithospheric structure across the Adamawa plateau (Cameroon) from gravity studies. Tectonophysics $273,317-327$.

[29] Ngako, V., Njonfang, E., Aka, F.T., Affaton, P., Nnange, J.M., 2006. The North-South paleozoic to Quaternary trend of alkaline magmatism from Niger-Nigeria to Cameroon: Complex interaction between hotspots and Precambrian faults. Journal of African Earth Sciences 45, 241-256.

[30] Gountié D. M., Nédélec A., Nono A., Njanko T., Font E., Kamgang P., Njonfang E., Launeau P., 2011. Magnetic fabrics of the Miocene ignimbrites from West-Cameroon: Implications for pyroclastic flow source and sedimentation. Journal of Volcanology and Geothermal research 203 (2011) $113-132$.

[31] Cox K.G., Bell J. D., \& Pankhurst R. J., 1979. The Interpretation of Igneous Rocks. George Allen \& Unwin.

[32] Middlemost E.A.K., 1975. The basalt clan, Earth Sci. Rev. 11 337-364.

[33] Evensen N.M., Hamilton M.J., and Nions R.J.O., 1978. "Rare Earth Abundances in Chondritic Meteorites geochemica et Cosmochemica Acta, Vol. 42, pp. 1199- 1212.

[34] Bevins R.E., Kokelaar B.P. and Dunkley P.N., 1984. Petrology and Geochemistry of lower to middle Ordovician Igneous rocks in Wales: a volcanic arc to marginal basin transition. Proc. Geol. Ass., 95, 337-347.

[35] Xu H., Chen J., Lu Z., 2014. Geological and Geochemical characteristics of Basalts from Hardat Togoi mine, Inner Mongolia, China. Chinese Journal of Geochemistry, Springer Journals. 33 pp 145-154.

[36] Thompson R.N and Morrison M.A., 1988. Asthenospheric and lower-lithospheric mantle contributions to continental extensional magmatism: an example from the British Tertiary Province: Chemical Geology. Volume 68, issues 1-2, 1988, pages 1-15.

[37] Bogaard P.J.F., Wörner G, 2003. Petrogenesis of basanitic to tholeiiticvolcanic rocks from the Miocene Vogelsberg, Central Germany, J. Petrol.44. 569-602.

[38] Déruelle B., Bardintzeff J.M., Cheminée J.L., Ngounouno I., Lissom J., Nkoumbou C., Etamé J., Hell J.V., Tanyileke G., N'ni J., Bekoa A., Ntepe N., Nono A., Wandji P., Fosso J., Nkouathio D.G. 2000. Éruptions simultanées de basalte alcalin et de hawaiite au mont Cameroun (28 mars-17 avril 1999), C. R.Acad. Sci.Paris, Ser. IIa 331. 525-531. 
[39] Yokoyama, T., Aka, F.T., Kusakabe, M., Nakamura, E., 2007. Plume-lithosphere interaction beneath Mt. Cameroon volcano, West Africa: constraints from 238U- 230Th-226Ra and Sr$\mathrm{Nd}-\mathrm{Pb}$ isotopic systematics. Geochimica et Cosmochimica Acta71, 1835-1854.
[40] Pearce, J. A., Norry, M. J., 1979. Petrogenetic implications of $\mathrm{Ti}, \mathrm{Zr}, \mathrm{Y}$, and $\mathrm{Nb}$ variations in volcanic rocks. Contributions to Mineralogy and Petrology69, pp. 33-47. 